\title{
Genetic characterization of S1 gene of infectious bronchitis virus isolated from commercial poultry flocks in West Java, Indonesia
}

\author{
Rahajeng Setiawaty ${ }^{1,2}$, Retno Damajanti Soejoedono² and Okti Nadia Poetri² \\ 1. National Veterinary Drug Assay Laboratory, Jl Raya Pembangunan, Gunung Sindur, Bogor 16340, Indonesia; \\ 2. Department of Animal Diseases and Veterinary Public Health, Faculty of Veterinary Medicine, Bogor Agricultural \\ University, Jl. Agatis, Kampus IPB, Dramaga, Bogor 16680, Indonesia. \\ Corresponding author: Rahajeng Setiawaty, e-mail: ajengfkh99@gmail.com \\ Co-authors: RDS: retnodmail@yahoo.com, ONP: diapoetri@gmail.com \\ Received: 13-09-2018, Accepted: 20-12-2018, Published online: 11-02-2019
}

doi: 10.14202/vetworld.2019.231-235 How to cite this article: Setiawaty R, Soejoedono RD, Poetri ON (2019) Genetic characterization of S1 gene of infectious bronchitis virus isolated from commercial poultry flocks in West Java, Indonesia. Veterinary World, 12(2): 231-235.

\begin{abstract}
Background and Aim: Infectious bronchitis (IB) is still a major problem among poultry industry in Indonesia, IB outbreaks continue to happen even in vaccinated flocks. The emergence of new IB virus (IBV) variants might lead to mismatching between vaccine virus strain and circulating virus strain, this may be a reason of vaccination failure. Information about circulating IBV in a region is important to decide which IB vaccine should be used. However, information about recent IBV strains which circulated in Indonesia and their genetic characters were limited; therefore, the aim of our research was to determine the genetic characterization of S1 gene of IBV isolated from commercial poultry flocks in West Java, Indonesia.

Materials and Methods: A total of 47 viral isolate samples collected from chickens with clinical sign and reduced in egg production. Six IB live vaccines were used as control, the reference vaccines represent IBV strains including H120, H52, 4/91, CR88, 233A, and 1-96. Primers XCe2+ and XCe2- were used to amplify S1 gene partially.

Results: Twenty-six of 47 samples showed positive result to $\mathrm{S} 1$ gene of IBV by reverse transcription-polymerase chain reaction. Three IBV isolates, Indonesia/K233A31/18, Indonesia/K4A9/17, and Indonesia/P3/17, were selected for nucleotide sequencing. Phylogenetic analysis of 352 nucleotides of the partial S1 gene shows that isolates Indonesia/K4A9/17 and Indonesia/K233A31/18 have 100\% homology with IBV vaccine strain 4/91, while isolate Indonesia/P3/17 has $100 \%$ homology with IBV vaccine strain 233A.
\end{abstract}

Conclusion: Our result indicates that at least two IBV strains were circulating among poultry in West Java, Indonesia, which is IBV close to vaccine strain $4 / 91$ and $233 \mathrm{~A}$. The present study provides updates on the circulating IBV in commercial poultry flocks in West Java, Indonesia, and might use as guidance on selecting a proper IB vaccine strain to improve IB vaccination efficacy in certain region.

Keywords: genetic characterization, Indonesia, infectious bronchitis virus, poultry, S1 gene, West Java.

\section{Introduction}

Infectious bronchitis (IB) is a poultry disease caused by Coronavirus of Nidovirales order [1]. Coronavirus is enveloped, non-segmented, single-stranded, and RNA's positive sense, comprises approximately $27-32 \mathrm{~Kb}$ in size [2]. All Coronaviruses have four structural proteins, glycoprotein spike, matrix, nucleoprotein, and envelope consist of lipid bilayer and three glycoprotein $\mathrm{M}, \mathrm{S}$, and HE [3]. The S protein has two glycopolypeptide components which are S1 and S2. The spike protein S1 undergoes inhibitor of agglutination and induces neutralizing antibody [2]. S1 protein functioned as differentiating factor among IB virus (IBV) strains and as a main target of genotype characterization. It also

Copyright: Setiawaty, et al. Open Access. This article is distributed under the terms of the Creative Commons Attribution 4.0 International License (http://creativecommons.org/licenses/ by/4.0/), which permits unrestricted use, distribution, and reproduction in any medium, provided you give appropriate credit to the original author(s) and the source, provide a link to the Creative Commons license, and indicate if changes were made. The Creative Commons Public Domain Dedication waiver (http:// creativecommons.org/publicdomain/zero/1.0/) applies to the data made available in this article, unless otherwise stated. plays an important role in attachment and virus entries into cells through cyanic acid receptor [4]. Amino acid variation in glycoprotein S1 took important place to tissue tropism and IB virulence [5].

IB is still a serious problem among poultry industry in Indonesia, the prevalence of the disease is $40-60 \%$ in Java Island [6]. Outbreaks were also occurred at vaccinated flocks, indicating vaccination failure; however, vaccination is the only practical means of controlling IB. Problem in vaccination is that it is only partially successful due to the continual emergence of antigenic variants. IBV strains within a geographic region are unique, even many countries share same antigenic types, so the selection of an appropriate antigenic type for the region is important, given the existence of wide antigenic variation [7]. The variants of IBV have not been well-documented in Indonesia since the lack of the characterization of this virus [8]. Understanding epidemiological condition and virus changes are important in designing IB vaccination strategies, to provide greater protection against enzootic strains, and the vaccination must be commonly practiced based on the field needs [9]. 
The previous study showed that the majority of IBV strain isolated in Indonesia were related to Massachusetts (Mass) and Connecticut (Conn), and serotype N2/62 originated from Australia [10], IBV local isolates [11], IBV close to vaccine virus strain 4/91 [12], and IBV originated from Taiwan and China [8].

However, limited information available about IBV strain circulating among poultry in Indonesia and its genetic character; therefore, the aim of our study was to determine IBV field strain and genetic characterization of S1 gene of IBV isolated from poultry in West Java, Indonesia, to provide an update on cocirculating IBV variants in this region.

\section{Materials and Methods}

\section{Ethical approval}

The present study was performed in accordance with the regulations for Research in Animal Health of Indonesian Law on Livestock and Animal Health (UU/18/2009, article 80).

\section{Samples}

A total of 47 samples isolated from problematic flocks showing IB such as clinical symptoms and reduction in production were used in this study. The samples were collected from commercial poultry flocks in some district in West Java Province: Sukabumi $(n=36)$, Cianjur $(n=1)$, Tasikmalaya $(n=4)$, Bogor $(n=4)$, and Subang $(n=2)$. The samples were organ, cloacal swab, and tracheal swab. Six IB live vaccines were used as positive control, the vaccine represents IBV strain H120, H52, 4/91, CR88, 233A, and 1-96.

\section{Viral RNA extraction}

Viral RNA was extracted using the total RNA Mini Kit (Geneaid $\AA)$, extraction procedure was based on manufacturer's instructions. The RNAs were dissolved in $50 \mu \mathrm{l}$ RNase-free water and directly used for subsequent reverse transcription-polymerase chain reaction (RT-PCR) or stored at $-20^{\circ} \mathrm{C}$.

\section{Primers for amplification}

Partial S1 gene amplification using one pair of primer [13]: Forward XCE2+5'-CAC TGG TAA TTT TTC AGA TGG-3' and reverse XCE2-5'-CCTC TAT AAA CAC CCT TACA-3', the expected PCR product size is $466 \mathrm{bp}$.

\section{Amplification}

The PCR amplification reaction was carried out in $50 \mu \mathrm{l}$ containing $5 \mu \mathrm{l}$ RNA template, $25 \mu \mathrm{l} 2 \times$ MyTaq one step mix (1×), $0.5 \mu \mathrm{RT}, 1 \mu \mathrm{l}$ Ribosafe RNAse inhibitor, DEPC- $\mathrm{H}_{2} \mathrm{O}$ (MyTaq ${ }^{\mathrm{TM}}$ OneStep RT-PCR Kit) up to $45 \mu 1$, and $4 \mu 1$ primer (400 nM). Amplification reaction was carried out with thermal profile at $45^{\circ} \mathrm{C}, 20 \mathrm{~min}$ RT $95^{\circ} \mathrm{C}, 1 \mathrm{~min}$ polymerase activation, then 40 cycles (denaturation $94^{\circ} \mathrm{C}, 15 \mathrm{~s}$; annealing $55^{\circ} \mathrm{C}, 30 \mathrm{~s}$; and extension $72^{\circ} \mathrm{C}, 30 \mathrm{~s}$ ) followed by final extension $72^{\circ} \mathrm{C}, 7 \mathrm{~min}$.

\section{Nucleotide sequencing}

About $30 \mu 1$ each of RT-PCR product of amplified $\mathrm{S} 1$ sequenced using BigDye ${ }^{\circledR}$ Terminator version 3.1 Cycle Sequencing Kit (Thermo Fisher Scientific, USA) with forward XCE2+ and reverse XCE2primer. These samples were sent for sequencing (First Base, Malaysia) and sequenced from both directions. The sample nucleotide sequence results are compiled, aligned, and compared with sequence of S1 gene of control positive and also with sequence data of S1 gene of published IBV available in the GenBank (Table-1). Phylogenetic trees were constructed using maximum likelihood of the general time reversible model of MEGA 7 software (http://www.megasoftware.net) $[14,15]$.

\section{Results}

Twenty-six of 47 samples showed positive result to S1 gene of IBV by RT-PCR. These samples were isolated from three different farms in West Java; therefore, we choose three positive samples only, one viral isolate from each farm for further nucleotide sequencing analysis. These three isolates are Indonesia/ K4A9/17 and Indonesia/P3/17 from Sukabumi, while Indonesia/K233A31/18 from Bogor.

Nucleotide sequencing of 352 nucleotide partial gene $\mathrm{S} 1$ indicates that isolates Indonesia/K4A9/17 and Indonesia/K233A31/18 have 100\% homology with IBV vaccine strain 4/91, while isolate Indonesia/ $\mathrm{P} 3 / 17$ has $100 \%$ homology with IBV vaccine strain 233 A. Among these three IBV isolates, the deviation between Indonesia/K4A9/17 and Indonesia/ K233A31/18 was $0 \%$, while Indonesia/K4A9/17 and Indonesia/K233A31/18 deviate $0 \%$ to Indonesia/

Table-1: Nucleotide and amino acid identity of selected IBV isolates and vaccine strains.

\begin{tabular}{lccccccccc}
\hline Samples & $\mathbf{1}$ & $\mathbf{2}$ & $\mathbf{3}$ & $\mathbf{4}$ & $\mathbf{5}$ & $\mathbf{6}$ & $\mathbf{7}$ & $\mathbf{8}$ & $\mathbf{9}$ \\
\hline & & & \multicolumn{7}{c}{ Amino acid identity } \\
H120 & & 0.25 & 0.27 & 0.28 & 0.28 & 0.26 & 0.26 & 0.26 & 0.28 \\
4/91 & 0.26 & & 0.07 & 0.07 & 0.08 & 0.10 & 0.01 & 0.01 & 0.07 \\
CR288 & 0.28 & 0.03 & & 0.04 & 0.10 & 0.10 & 0.06 & 0.06 & 0.04 \\
233A & 0.27 & 0.03 & 0.02 & & 0.08 & 0.06 & 0.07 & 0.07 & 0.00 \\
1/96 & 0.27 & 0.05 & 0.06 & 0.05 & & 0.10 & 0.09 & 0.09 & 0.08 \\
H52 & 0.23 & 0.05 & 0.05 & 0.03 & 0.07 & & 0.11 & 0.11 & 0.06 \\
Indonesia/K233A31/18 & 0.26 & 0.00 & 0.03 & 0.03 & 0.05 & 0.05 & & 0.00 & 0.07 \\
Indonesia/K4A9/17 & 0.26 & 0.00 & 0.03 & 0.03 & 0.05 & 0.05 & 0.00 & & 0.07 \\
Indonesia/P3/17 & 0.27 & 0.03 & 0.02 & 0.00 & 0.05 & 0.03 & 0.03 & 0.03 & \\
\hline
\end{tabular}

Nucleotide identity, IBV=Infectious bronchitis virus 
P3/17. Difference of S1 gene sequence between these three IBV isolates with other vaccine strain was $2-29 \%$ (Table-1). There was no deletion or insertion occurred inside the S1 genes. Point mutation throughout nucleotide sequences was not detected either (Figure-1).

There are 11 nucleotide differences within three IBV isolates (Table-1). Differences between three samples located in nucleotides: 749, 790, 808, 824, 988, 1008, 1097, 1103, 1131, 1133, and 1137. There are no changes in amino acid residue - 304 that correlated with nucleotide - 894. There are no changes in nucleotide order A-ACA-G from cytosine to timina and amino acid histidine from the three samples or vaccine strain. XCE primers used in this study only able to amplify third quarter part of hypervariable regions 3 (HVRs 3) in S1 gene, whereas HVRs 3 located at amino acid residue 274-387. Amino acid residue indicates no deletion, insertion, or mutation at position 298 (Histidine) (Figure-1).

The phylogenetic tree (Figure-2) of the aligned nucleotide of partial S1 gene was constructed using maximum likelihood of the general time reversible model of MEGA 7 (www.megasoftware.net) [14,15], the tree showed a close relatedness of two IBV isolates (Indonesia/K4A9/17 and Indonesia/K233A31/18) with reference IBV strain 793 (Accession No. Z83979), strain 793B (Accession No. KF377577), strain 793B (Accession No. AF093793), strain 793B (Accession No. AF093794), and strain 491 (Accession No.
JN1921541) isolated in the United Kingdom (UK), while other isolate Indonesia/P3/17 has close relatedness to reference IBV strain 233A (Accession No. JQ946056), Variant 1 (Accession No. AF093795), and strain 1/96 793B (Accession No. AF093795) isolated from Israel, the United States of America (USA), and the UK, respectively. Based on genetic characterization on $\mathrm{S} 1$ gene sites, isolates Indonesia/K4A9/17 and Indonesia/K233A31/18 were likely belonged to IBV close to vaccine strain $4 / 91$, and isolate Indonesia/ P3/17 likely belonged to IBV close to vaccine strain 233A.

\section{Discussion}

Ronoharjo, in 1977, was the first who isolated IBV in Indonesia, a few years later Darminto in 1985 were able to isolated IBV [8]. These viruses belonged to four serotypes group: One group close to IBV Mass, another close to IBV Conn, and the other two groups close to IBV from Australia [10]. The emergence of IBV variants in Indonesia was first detected by Dharmayanti et al. [16], and later on, the study of IBV variants was conducted by Dharmayanti and Indriani [8] which detected IBV variants close to Taiwan and China strain. IBV has a high capacity for genetic change through mutation, and these genetic mechanisms might lead to emergence of new IBV serotypes and variants and evolution of IBV also influenced by application of multiple vaccine strain [17-19].

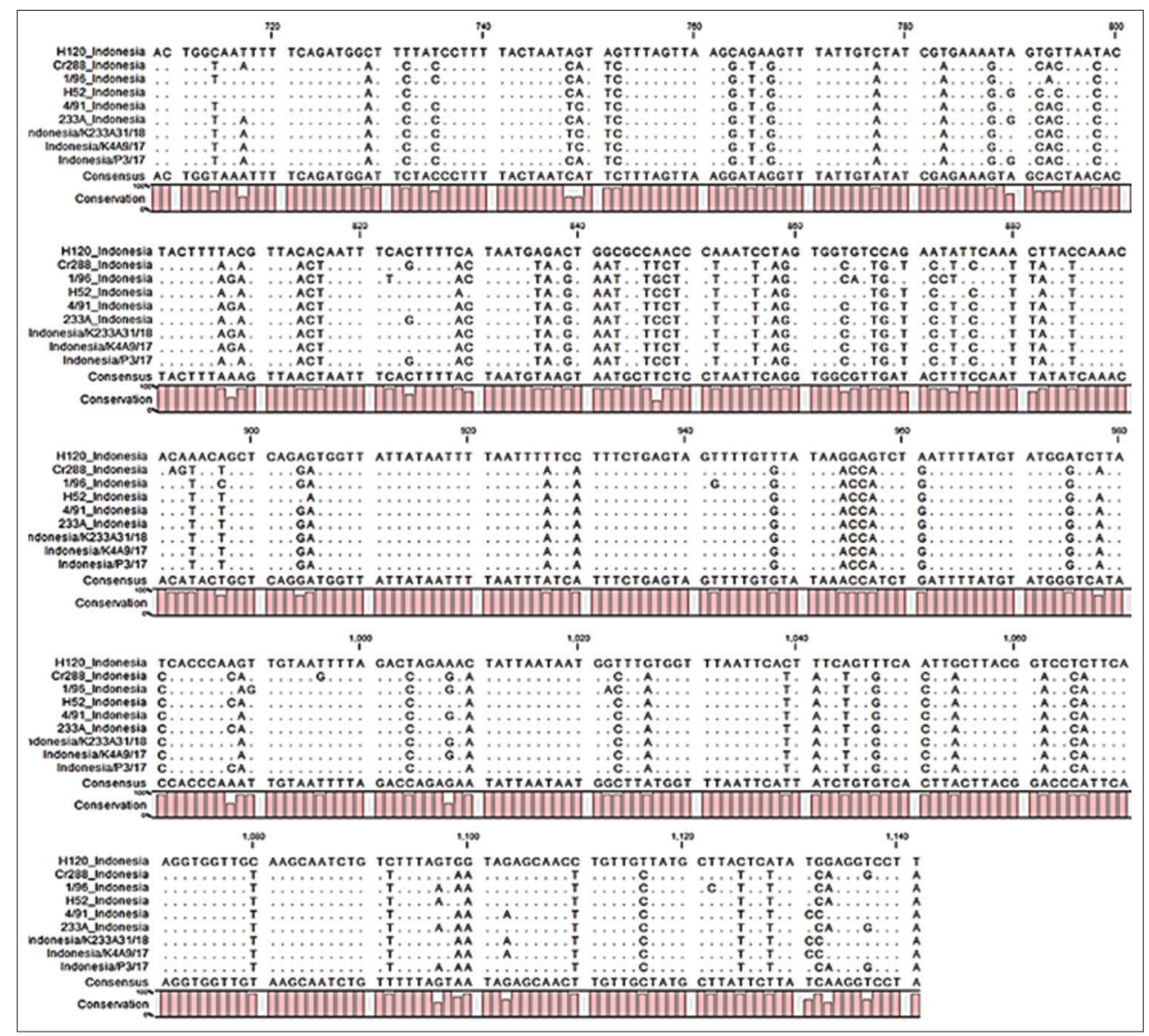

Figure-1: Partial sequence of the S1 gene of infectious bronchitis virus isolates and vaccine strain. 


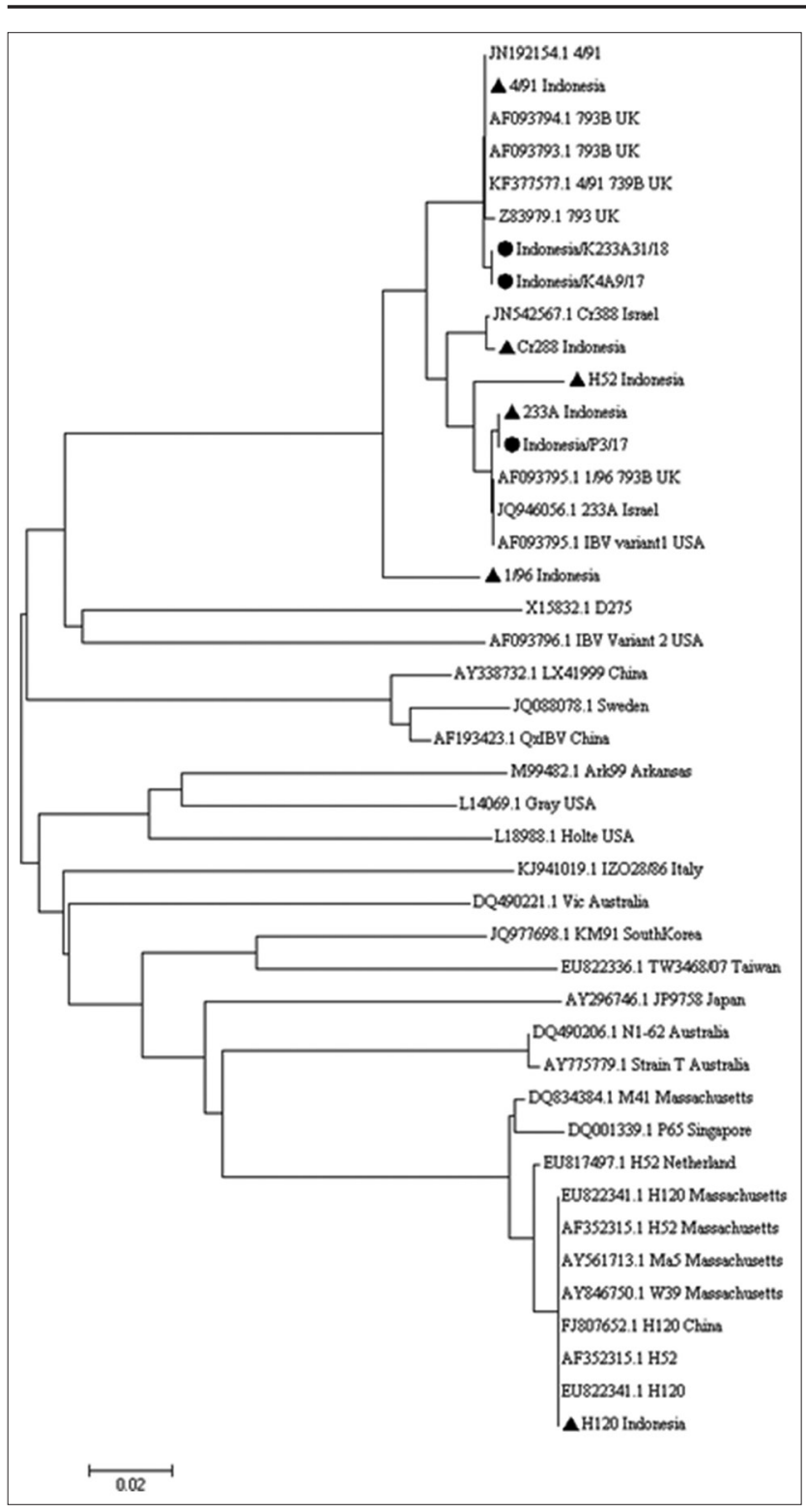

Figure-2: Phylogenetic tree of selected infectious bronchitis virus (IBV) isolates, vaccine virus, and other IBV from GenBank. IBV Indonesia/K23331A/18, Indonesia/ $\mathrm{K} 4 \mathrm{~A} 9 / 17$, and Indonesia/P3/17 $(\bullet)$, vaccine virus $(\boldsymbol{\Delta})$, and IBV from GenBank.

Therefore, updating epidemiological status of IBV through genetic characterization is important for designing appropriate vaccination program in a certain region.

The spike protein or S1 subunit of S glycoprotein is the major determinant of IBV so that a minor change in amino acid sequence of this protein would transform the virus strain [20]. Changes in amino acid of $\mathrm{S} 1$ gene $>5 \%$ may result in reducing the ability of a vaccine to protect an individual from field virus attack [21]. Determinant region for IB serotyping was located in the first 395 amino acid of S1 gene. Amino acid epitopes play an important role in virus critical antigenic were located at position 296 (amino acid Glutamine, Threonine and Alanine replaced by Histidine, Threonine and Alanine or Serine, Threonine and Alanine) and position 378 (amino acid Proline,
Arginine and Glycine replaced by Proline Arginine Leucine, these substitutions cause decreasing of vaccine protection and produced new IBV strain. Variation of nucleotides and amino acids may lead to serotype changes, which, in turn, changes tissue tropism and pathogenicity of the virus [22].

Based on our partial sequence of S1 gene results, there are no substitutions in 894-nt and amino acid residue - 298. Partial nucleotide sequencing of S1 gene of IBV Indonesia/K4A9/17 and IBV Indonesia/ K233A31/18 was $100 \%$ identical with vaccine strain $4 / 91$, and IBV Indonesia/P3/17 was $100 \%$ identical to vaccine strain $233 \mathrm{~A}$. No mutation, insertion, or deletion detected in nucleotide sequence of IBV isolates in this study. An explanation could be that, this is resulted from reisolation of vaccine strain virus circulating in the susceptible host or there is high recombination of IBV genome during cocirculation of vaccine virus and field virus $[18,19]$.

Phylogenetic three showed that three IBV isolates were relatively close to IBV from the UK, Israel, and the USA, respectively. In Indonesia, a latest study about genetic characterization of IBV isolated by Dharmayanti and Indriani [8] showed that two cocirculating IBV IB/WJ.2010 and IB/JB.1990 were close to IBV originating from China, while other IBV IB L8.1996 was close to IBV originating from Taiwan, and all of these strain did not show proximity to vaccine strain M41, H120, and Conn which is widely used in Indonesia. The present study indicates that during these years, IBV circulating in Indonesia has been evolved. The continuous existence of IBV variant in the field shows the importance of regular surveillance to get an update on epidemiological situation of IB infection and emerges of new IBV variants to improve efficacy of IBV control strategies in certain country.

\section{Conclusion}

The present study provides updates on the circulating IBV in commercial poultry flocks in West Java, Indonesia. Partial sequencing of the S1 gene revealed at least two IBV strains circulating among poultry in West Java, which is IBV close to vaccine strain 4/91 and IBV close to strain 233A. Based on phylogenetic three, these three isolates were relatively close to IBV from the UK, Israel, and the USA, respectively.

\section{Authors' Contributions}

RS performed the work designed by RDS and ONP. All authors contributed in writing and revision of the manuscript. All authors read and approved the final manuscript.

\section{Acknowledgments}

The authors would like to thank Marwan Nasution, for supporting samples from commercial poultry flocks. The authors would like to thank PT Intervet Indonesia, for supporting funds for this study. 


\section{Competing Interests}

This study was funded by PT Intervet Indonesia but no one from this company was involved at any stage of the study. Also, we have not used any commercial product of PT Intervet Indonesia for this study. The authors declare that they have no competing interests.

\section{Publisher's Note}

Veterinary World remains neutral with regard to jurisdictional claims in published institutional affiliation.

\section{References}

1. Cavanagh, D. (2005) Coronavirus in poultry and other birds. Avian Pathol., 34(6): 439-448.

2. Cavanagh, D. and Gelb, J.Jr. (2008) In: Disease of Poultry, Saif, Y.M., Fadly, A.M., Glisson, J.R., McDouglad, L.R., Nolan, L.L. and Swayne, D.E., editors. Infectious Bronchitis. $12^{\text {th }}$ ed. Blackwell Publishing, Ames. p117-135.

3. Bande, F., Arshad, S.S., Omar, A.R., Bejo, M.H., Abubakar, M.S. and Abba, Y. (2016) Pathogenesis and diagnostic approaches of avian infectious bronchitis. Adv. Virol., 2016(23): 1-11.

4. Jackwood, M.W., Hall, D. and Handel, A. (2012) Molecular evolution and emergence of avian gammacoronaviruses. Infect. Gen. Evol., 12(6): 1305-1311.

5. Madu, I.G., Chu, V.C., Regan, A.D., Bauman, B.E. and Whittaker, G.R. (2007) Heparan sulfate is a selective attachment factor for the avian Coronavirus infectious bronchitis virus beaudette. Avian Dis., 51(1): 45-51.

6. Darminto, D. (1995) Diagnosis Epidemiology and Control of Two Mayor Avian Viral Respiratory Disease in Indonesia; Infectious Bronchitis and Newcastle Disease. Thesis. North Queensland, Australia, James Cook University.

7. Ignjatovic, J. and Sapats, S. (2000) Avian infectious bronchitis virus. Rev. Sci. Tech. Off. Int. Epiz., 19(12): 493-508.

8. Dharmayanti, N.L.P.I. and Indriani, R. (2017) Identification and characterization of infectious bronchitis virus (IBV) in Indonesia. J. Biol. Ind., 13(1): 53-59.

9. Bourogâa, H., Larbi, I, Miled, K., Hellal, Y.K., Hassen, J., Behi, I., Nsiri, J. and Ghram, A. (2014) Evaluation of protection conferred by a vaccination program based on the H120 and CR88 commercial vaccines against a field variant of avian infectious bronchitis virus. Appl. Poult. Res.,
23(2): 156-164.

10. Darminto, D. (1992) Serotype of IB viral isolates. Penyakit Hewan, 24(44): 76-81.

11. Indriani, R. and Darminto, D. (2000) Serotype variation infectious bronchitis virus isolates from several regions in Java. J. Int. Tech. Vet., 5(4): 1-7.

12. Untari, T., Sardjono B., and Darjono D. (2003) Identification avian infectious bronchitis virus isolated from Yogyakarta using reverse transcriptase polymerase chain reaction gen peplomer S-1. J. Sain. Vet., 21(9): 47-50.

13. Jahantigh, M., Salari, S. and Hedayati, M. (2013) Detection of Infectious Bronchitis virus serotypes by reverse transcription polymerase chain reaction in broiler chickens. Springer Plus, 2(1): 36.

14. Nei, M. and Kumar, S. (2000) Molecular Evolution and Phylogenetics. Oxford University Press, New York.

15. Kumar, S., Stecher, G. and Tamura, K. (2016) MEGA7: Molecular evolutionary genetics analysis version 7.0 for bigger datasets. Mol. Biol. Evol., 33(7): 1870-1874.

16. Dharmayanti, N.L.P.I., Asmara, W., Arthama, W.T., Indriani, R. and Darminto, R. (2003) Sequence comparison of hypervariable region (HVR) of subunit S1 gene of infectious bronchitis virus of field isolate I-37 and serotypes connecticut 46. J. Int. Tech. Vet., 8(4): 107-113.

17. Thor, S.W., Hilt, D.A., Kissinger, J.C., Paterson, A.H. and Jackwood, M.W. (2011) Recombination in avian gammacoronavirus infectious bronchitis virus. Viruses, 3(9): 1777-1799.

18. Lee, C.W. and Jackwood, M.W. (2001) Origin and evolution of Georgia 98 (GA98), a new serotype of avian infectious bronchitis virus. Virus Res., 80(1-2): 33-39.

19. Jackwood, M.W., Hall, D. and Handel, A. (2012) Molecular evolution and emergence of avian gammacoronaviruses, infection, genetics and evolution. J. Mol. Epid. Evol. Gen. Infect., 12(6): 1305-1111.

20. Bakhshesh, M., Masoudi, S., Esmaelizad, M. and Khalesi, B. (2016) S1 gene sequence analysis of infectious bronchitis virus vaccinal strains (H120 \& H52) and their embryo-passaged derivatives. Arch. Razi Inst., 71(2): 87-96.

21. Zanaty, A., Naguib, M.M., El-Husseiny, M.H., Mady, W., Hagag, N. and Satar-Arafa, A. (2016) The sequence of the full spike S1 glycoprotein of infectious bronchitis virus circulating in Egypt reveals evidence of intra-genotypic recombination. Arch. Virol., 161(12):3583-3587.

22. Hassan, K.E., Shany, S.A.S., Ali, A., Dahsan, A.H.M., El-Sawah, A.A. and El-Kady, M.F. (2016) Prevalence of avian respiratory viruses in broiler flock in Egypt. Poul. Sci., 95(6): 1271-1280. 